\title{
Striving for Social Justice and Equity in Higher Education
}

\section{education policy analysis archives}

A peer-reviewed, independent, open access, multilingual journal

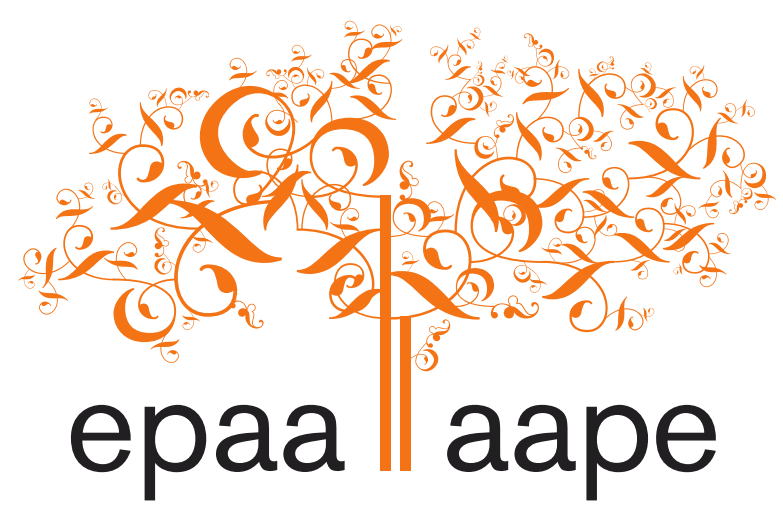

Arizona State University

\section{Examining the Continuum of Black Student Leadership: From Community to College and Beyond}

\author{
Bryan K. Hotchkins \\ \& \\ Jon McNaughtan \\ Texas Tech University \\ United States
}

Citation: Hotchkins, B. K., \& McNaughtan, J. (2021). Examining the continuum of Black student leadership: From community to college and beyond. Education Policy Analysis Archives, 29(42). https://doi.org/10.14507/epaa.29.4695 This article is part of the special issue, Striving for Social Justice and Equity in Higher Education, guest edited by Irina Okhremtchuk, Caroline Turner, \& Patrick Newell.

Abstract: This qualitative comparative case study examines the leadership involvement of 11 Black collegians and how they make sense of enacting transgenerationally informed knowledge(s) as racial socialization to navigate a predominantly White institution (PWI) campus. Findings indicated participants used elder communal instruction and parental home pedagogy to inform what it means to be leaders who enact social justice while Black. Emergent themes were: 1) Collective Definition; and 2) Self-sacrifice. Participants indicated parents and elders racially socialized them to be selfsacrificing leaders who used values, respect, and honor to preserve Black culture, people, and 
traditions. Racial socialization processes influenced students to become leaders who built and sustained Black college communities by being resilient. Participants acknowledged that although resiliency was important there was added value in practicing racial resistance, which allowed for exposing racially threatening oppositions and identify acts of racism that were menacing.

Keywords: Black Student Leadership; Transgenerational; Activism

\section{Examinando el continuo del liderazgo estudiantil negro: De la comunidad a la universidad y} más allá

Resumen: Este estudio de caso comparativo cualitativo examina la participación de liderazgo de 11 universitarios negros y cómo les da sentido la promulgación de conocimientos informados transgeneracionalmente como socialización racial para navegar en un campus de institución predominantemente blanca (PWI). Los hallazgos indicaron que los participantes utilizaron la instrucción comunitaria para personas mayores y la pedagogía del hogar de los padres para informar lo que significa ser líderes que promulgan la justicia social mientras son negros. Los temas emergentes fueron: 1) Definición colectiva; y 2) Auto-sacrificio. Los participantes indicaron que los padres y ancianos los socializaban racialmente para que fueran líderes abnegados que usaban los valores, el respeto y el honor para preservar la cultura, la gente y las tradiciones negras. Los procesos de socialización racial influyeron en los estudiantes para que se convirtieran en líderes que construyeron y sostuvieron comunidades universitarias negras siendo resilientes. Los participantes reconocieron que, aunque la resiliencia era importante, la práctica de la resistencia racial tenía un valor agregado, lo que permitía exponer las oposiciones que amenazaban a la raza e identificar los actos de racismo.

Keywords: Liderazgo estudiantil negro; Transgeneracional; Activismo

\section{Examinando o continuum da liderança do estudante negro: Da comunidade à faculdade e além}

Resumo: Este estudo de caso comparativo qualitativo examina o envolvimento de liderança de 11 universitários negros e como eles entendem a promulgação de conhecimento (s) transgeracionalmente informado (s) como socialização racial para navegar em um campus de instituição predominantemente branca (PWI). Os resultados indicaram que os participantes usaram instrução comunitária para idosos e pedagogia familiar para informar o que significa ser líderes que promovem justiça social enquanto negros. Os temas emergentes foram: 1) Definição Coletiva; e 2) Auto-sacrifício. Os participantes indicaram que pais e idosos os socializaram racialmente para serem líderes abnegados que usaram valores, respeito e honra para preservar a cultura, o povo e as tradições Negras. Os processos de socialização racial influenciaram os alunos a se tornarem líderes que construíram e sustentaram comunidades universitárias negras por serem resilientes. Os participantes reconheceram que, embora a resiliência fosse importante, havia valor agregado na prática da resistência racial, o que permitia expor oposições racialmente ameaçadoras e identificar atos de racismo.

Keywords: Liderança do estudante negro; Transgeracional; Ativismo 


\section{Introduction}

The Obama era of encouraging people to possess an "audacity to Hope" has dramatically shifted from an overarching American culture of valuing diversity and ethnic acceptance to that of anti-Blackness. For example, Blackface instances at Colorado State University and the University of Oklahoma (Hernandez, 2019a; Kirker, 2019a) coupled with nooses publicly displayed at Stanford University and University Illinois (Beachum, 2019; Shalby, 2019) provide relevant examples of how racism looks at predominantly White institutions since White Supremist marched with Tiki torches at the University of Virginia (Peters \& Besley, 2017). Although the abovementioned racist instances elucidate the rationale for current Black collegians to be involved in social justice engagement, they also speak to a sense of perpetual generational urgency that Black people have dealt with throughout the Jim Crow and school to prison pipeline eras. To this point, the pursuit of social justice by descendants of the African Diaspora has evolved during the past 75 years to include the organized efforts of emancipatory groups such as the Black Panther Party, Student Nonviolent Coordinating Committee (SNCC), National Association for the Advancement of Colored People (NAACP) and recently Black Lives Matter (Garza, 2014; Peniel, 2003; White, 2016). Specifically created to challenge systemic anti-Blackness efforts, dismantle school to prison pipeline initiatives, and blatantly deconstruct platforms that embolden racism, activism by these groups has historically provided opportunities for transgenerational protest, which includes elder-parent-child activism, within communities of color and on college campuses (Dohrn \& Ayers, 2016; Joshi et al., 2017).

To illustrate, the scope and sequence of modern Black politicism is reminiscent of the Black Action Movement (BAM), which consisted of various multicultural student led organizations that held a series of student protest in 1970, 1975, and 1987 to critique American society and interrogate the state international economic and political affairs. Specifically, protest held the University of Michigan accountable to create inclusive policies for the betterment an unwelcoming hostile campus racial climate to include the creation of a Black student center, Black Studies program and supportive "minority" student services (Bryant, 2007). Examples like these empowered Black leaders to purposefully pursue the elimination of inequity on their campuses and within their communities, thereby creating a template for how to engage in social justice activism, which provided the catalyst for other Black collegians to be actively involved on their college campuses. In the abovementioned BAM example students utilized organizations to practice social justice activism, which impacted their persistence at predominantly White institutions' (PWIs) across the nation. These experiences with racism, while attending PWIs, are informed by the legacy of scholars like Du Bois (1965) and Fanon (1967) that focuses on the state of colonized Black people globally. Specifically, how systems of oppression, which includes settler colonial institutions of higher education, consistently remind people of African descent about historic deficit framings of themselves as descents of the Transatlantic Slave Trade, juxtaposed to what it means to grapple with assimilation while seeking degree conferral.

In general, the various ways in which Black students experience being African immigrants and African American when in pursuit of degree attainment at predominantly White institutions (PWI) has been broached (Allen, 1987; DeSousa \& Kuh, 1996; Ervin, 2001; Flowers, 2002; Fleming, 1984; Harper \& Hurtado, 2007; Johnson \& Lane, 2016; Lyons, 1973; Patton et al., 2011). In particular, we understand that outcomes such as gendernoir racial battle fatigue (Hotchkins, 2017a), which is describes "the nuanced experiences of racial battle fatigue at the intersection of being women (e.g., gender) and Black (e.g., race)" (p. 2), can result when Black students are exposed to hostile PWI campus racial climates for prolonged periods of time (Fleming, 1984; Hurtado et al., 2015; Rankin \& Reason, 2005). To illustrate, when Black students are immersed in a college White 
institutional presence (WIP) varied forms of racial trauma are seen and felt that include academic discrimination, cultural marginalization, and social isolation as a consequence to racism (Black, 2004; Cooke, 2002; Thompson, 2000; Wallace \& Bell, 1999). Gusa (2010) stated 'WIP is the institutionalized fusion of White worldview, White supremacy, and White privilege, and the manifestation of WIP can be categorized into four intricately linked attributes: White ascendancy, monoculturalism, White blindness, and White estrangement" (p. 472). Cumulatively, these attributes manifest holistically as deleterious to Black students whether in the form of subdued racial microaggressions (Harris et al., 2015; Hollingsworth et al., 2018; Nadal et al., 2014; Robinson-Wood et al., 2015; Sue, 2010) or as flagrant racism (Brown, 2018; Kelly, 2018; Smith et al., 2007)—both having a lasting impact degree attainment.

Subsequently, Black students who traverse WIP environments by practicing social justice activism as leaders in historically Black and predominantly White co-curricular organizations do so by means of online involvement to avert racism-based circumstances (Sandoval-Almazan \& GilGarcia, 2014; Schuschke \& Tynes, 2016). These culturally compromising situations place Black students in psychological, physiological and behavioral jeopardy while pursuing degree attainment (Arminio et al., 2000; Chatters, 2018; Hotchkins \& Dancy, 2017; Sutton \& Kimbrough, 2001). As it pertains to participants in this study, the personal rationale for social justice pursuits is informed by elders and parents of Black student leaders who were raised within communities that valued activism and socialized their children to do the same. In fact, these emancipatory ontological, epistemological and axiological perspectives are inculcated throughout child, adolescent and young adult years as a form of racial socialization grounded in Black liberation philosophy (Herndon \& Hirt, 2004; Peters, 1985; Stevenson, 1994). To illustrate, philosophies of racial preservation stem from ancestral narratives about enduring Chattel Slavery, Jim Crow, Black Codes, Segregation, and school to prison pipelines (Hartman, 2007; Womack, 2017) that adversely impact descendants of the African Diaspora in perpetuity.

The purpose of this qualitative comparative case study is to examine how Black student leaders make sense of enacting transgenerationally informed social justice pursuits, based on racial socialization, while attending a PWI campus. Drawing upon the lived experiences of 11 participants, this study informs current research by further explaining how these students strategically navigate PWI environments. Participants enacted social justice in an attempt to resist, re-organize and restructure exclusionary systems (e.g., student government funding policies) that influenced what was perceived as a hostile campus racial climate. Further, applied social justice tactics were directly informed by elders, parents and community members cultural contributions prior to and throughout participants attending college. Finally, we acknowledge that African and African American are not synonymous; however, participants used the terms interchangeably with Black to describe themselves and peers.

\section{Questions Guiding the Study}

The purpose of this study is to understand how Black student leaders make sense of enacting social justice as a result of transgenerational racial socialization to navigate college. The overarching lines of query that informed the study were:

1. How do Black student leaders experience enacting social justice on a PWI campus?

2. What do Black students value about transgenerational leadership knowledge shared by parents, elders, and members of their communities?

3. How are transgenerational leadership knowledges applied on campus? 
Authors also asked participants questions about what it meant to be a leader, how they defined social justice, and to what extent being Black as coupled to a legacy of ancestral oppression informed self-perceptions of emancipatory practices.

\section{Literature Review}

What it means to be Black has been broached by varied scholars, but the Du Boisian (1903) definition of "double consciousness" has remained the quintessential framing:

Double-consciousness, this sense of always looking at one's self through the eyes of others, of measuring one's soul by the tape of a world that looks on in amused contempt and pity. One ever feels his two-ness, _ an American, a Negro. (1903, p. 9)

This perspective offered by Du Bois (1903) explores the conundrum experienced by American descendants of Africa who despise being ascribed as deficit while owning a positive sense of self that will likely never be accepted by White society. DuBois (1965) later conceptualized:

The history of the American Negro is the history of this strife - this longing to attain self-conscious manhood, to merge his double self into a better and truer self. In this merging he wishes neither of the older selves to be lost. He would not Africanize America...He would not bleach his Negro soul...He simply wishes to make it possible for a man to be both a Negro and an American, without being cursed and spit upon by his fellow, without having the doors of Opportunity closed roughly in his face. (p. 215)

These frames were offer a glimpse of evolution where the latter perspective constitutes a merger of what it means to be American and Black in a positive way that simultaneously embraces the past that is African heritage and present that is Black excellence.

Similarly, Fanon (1952) arrived at similar conclusions about 'double consciousness' being experienced by Black people globally, beyond an American context:

The Black man possesses two dimensions: one with his fellow Blacks, the other with the Whites. A black man behaves differently with a white man than he does with another black man. There is no doubt whatsoever that this fissiparousness is a direct consequence of the colonial undertaking," (p. 1).

In a subsequent iteration of the concept 'double consciousness' Fanon (1967) speaks to the context of Black identity within being colonized when he offered the notion that:

Overnight the Negro has been given two frames of reference within which he has to place himself... $[\mathrm{H}]$ is customs and the sources on which they are based, were wiped out because they were in conflict with a civilization that he did not know and that imposed itself on him. (p. 110)

This framing speaks to the heinous nature of White colonization as he acknowledges that it is difficult for colonized intellectuals to emancipate Black people if they speak, act and think like the White colonizer. Despite Du Bois' (1903, 1965) and Fanon's $(1952,1967)$ framing of “double consciousness" being nearly 110 years ago, contextualized research concerning similar experiences by Black students attending modern day PWIs (Arminio et al., 2000; Gin et al., 2017; Fleming, 1984; Harper, 1975; Hurtado et al., 1998; Kimbrough, 1995; Kimbrough \& Hutcheson, 1998; Patton et al., 2011; Person \& Christensen, 1996) has led to a single, overarching conclusion-to exist under the normative gaze of Whiteness often results in adverse social, academic and behavioral outcomes. Coping mechanisms are often found within family-based support systems that encourage holistic 
development and community contribution while attending college, where academic success is culturally demanded (Carter-Francique et al., 2015; Dennis et al., 2005; Johnson \& Lane, 2016) and the building of social capital is recognized.

In part, this desire to give back to their communities stems from Black students' racial socialization by their parents to see themselves as part of a Black collective that requires their service (Peters, 1985). Peters (1985) defines racial socialization as "tasks Black parents share with all parentsproviding for and raising children...but include the responsibility of raising physically and emotionally healthy children who are Black in a society in which being Black has negative connotations" (p. 161). The cultural transmission of Black values and beliefs serves as not only a source of prideful information concerning what it means to be Black, but also acknowledges "racial socialization messages are lifelong memories that make up 'Who I am' stories. They form the foundation of African American children's identities" (Stevenson, 1994, p. 193) that positively shape their world view. Various researchers also found cultural relevance of family influence as central to Black students' holistic growth that raises academic outcomes, scholarly self-esteem, validation of intellectual ability and entitlement to attend college due to having an awareness of interracial protocols (Bowman \& Howard, 1985; Dressier, 1987; Kiah, 1992; McAdoo, 1993). Furthermore, while academic achievement is a primary expectation of nuclear families, Black students are also provided emotional and social guidance through fictive kinships (Dressier, 1987; Herndon \& Hirt, 2004) that firmly frame community as the ultimate resource concerning how being Black and resilient looks at PWIs.

This assertion that Black families are a communal resource informs an understanding about how when in doubt Black students must not only thrive during uncertainty, but also were also prepared to be racially resiliency prior to attending college (Herndon \& Hirt, 2004; McAdoo, 1993). Similarly, Hotchkins (2017b) defines the racial resistance of Black collegians as "identifying racially threatening sources (e.g., White peers) and responding by developing strategies (e.g., organizing protest) to avert race-based trauma" (p. 270)—a liberatory process that is reminiscent of Black collegian's Civil Rights pursuits to secure social justice for Black people. To this point students engage in emancipatory activities as leaders in historically Black organizations (Dancy \& Hotchkins, 2015; Hotchkins \& Dancy, 2017; Patton et al., 2011; Sutton \& Kimbrough, 2001) where they further learn how to be socially responsible, challenge deficit stereotypes and respond to racism where threatening campus racial climates are prevalent (Dugan, 2006; Joseph, 2003; Morris, 1981; Robinson-Wood, 2009; Rosenthal, 1975; Sawyer III \& Palmer, 2014).

As a key example of Black development within leadership roles Harper and Quaye (2007) interviewed 32 high-achieving African American males about their organizational experiences and learned ethnic leadership opportunities honed their Black identity development by facilitating Black expression and validation. Moreover, these ethnic organizations cultivated moments for participants to engage in leadership situations where they learned cross-cultural communication skills that enabled them to better understand the experiences racially different peers, thereby informing advocacy for students of color who were also marginalized. Whether employing social justice strategies to hold universities accountable, to assure stable mental health by reversing intergenerational trauma, or proactively responding to sexual assault against LGBTQIA members (Barlow, 2018; Krause et al., 2017; Renn, 2007), Black students are actively involved in attacking systems of oppression to advance marginalized people to achieve the purposeful fulfillment of elders and parental expectations. This study converges with the abovementioned literature concerning how Black collegians participate in social justice, but it diverges in informing how transgenerational, proximal experiences with simultaneous systems, micro-, meso-, exo-, macro- and chronosystems 
Bronfenbrenner (1979, 1994, 2005), inform identity development of Black students who engage in social justice practices.

\section{Theoretical Framework}

\section{Ecological Environmental Model}

The ecological paradigm of Bronfenbrenner's (1979, 1994, 2005) was utilized to explore how Black student leaders make sense of enacting social justice as a result of transgenerational racial socialization (Herndon \& Hirt, 2004; Peters, 1985). Bronfenbrenner (2005) stated five simultaneous systems, micro-, meso-, exo-, macro- and chronosystems, inform identity development within children due to proximal interactions that are interpersonal. Specifically, child-child, parent-child, elder-child, and child-environmental interactions influence the ontological, epistemological and axiological perspectives of children. Micro- is defined as direct surroundings; Meso- links children to formative points of interaction (e.g. daycares); Exo- is representative of indirect human interactions (e.g. school principals); Macro- consists of engrained societal performances (e.g. anti-Blackness); and Chrono- represents influencers of identity development across the passage time. For the purpose of this paper, Bronfenbrenner's $(1979,1994,2005)$ framework operates in concert with two racial socialization models (Herndon \& Hirt, 2004; Peters, 1985) that rely on the passage of transgenerational knowledge for elders, parents and fictive kin directly to Black children, which constitutes a proximal process (Bronfenbrenner, 1994).

Each of the systems, micro-, meso-, exo-, macro- and chrono, informs this study to explain why participants construct social justice as necessary and to provide a transgenerational panoramic view about parental, elder and community expectations concerning the importance of explicitly performing emancipatory acts to engender equality. To illustrate, study participants mentioned instances when their elders described the urgency of avoiding perpetual systems of oppression (i.e. school to prison pipelines) that served as vestiges of chattel slavery (e.g., macro-system; Hartman, 2007; Womack, 2017) and were a direct reason to practice social justice. Since Bronfenbrenner's (2005) ecological system frames the development of children's identities as dependent on societal elements, based directly on proximal interactions with environmental stimuli, it is used to also illustrate how transgenerational interactions influence racial perceptions of participant's lives-to include those children who were raised in Black families where social justice culture was prime and therefore manifested in the actions of Black collegians who experienced these environments prior to arriving to campuses. These specific influences are based on nuclear, extended kin and fictive kin relationships where home pedagogies (Delgado Bernal, 2001) are exchanged and reinforced to inform contextual experiential sameness and difference across generations. For example, each participant lamented about discussions pertaining to proper police interaction protocols in order to preserve their humanity.

According to Peters (1985) the responsibility of Black families to their raise children holistically aware of what it means to exist in a world where racism occurs is prime. Herndon and Hirt (2004) postulated this contextual awareness can be achieved when Black "families provide the background for explaining meaning in life and the world. Another influence of family relates to social context. Parents provide students with a social environment that influences the way students view education" (p. 491). African American students' families primarily consist of nuclear, extended kin and fictive kin who are responsible for the establishment of "realistic" collegiate expectations that drive student pursuits and accountability, as well as how they see themselves in terms of being Black. Fictive kin are defined as "these kinds of kinship bonds are unrelated by blood; however, they are viewed as equally significant as blood relationships. Fictive kinship networks may include 
neighbors, church members, and friends" (Herndon \& Hirt, 2004, p. 493). Furthermore, racial socialization of Black children is essential to the preservation of Black communities where humane framings are coupled with cultural pride and a clear understanding that freedom is not free and requires the application of social justice to eradicate racism even on college campuses.

This study elucidates two points about how transgenerational knowledge as racial socialization informs the application of social justice on PWI campuses: (a) Black student leaders apply racial resistance to navigate college; (b) understand themselves as members of a vibrant contributing culture that is oppressed due to being Black; and (c) honors self-sacrifice in effort to preserve and elevate the racial whole.

\section{Methods and Data Sources}

Comparative case study (Yin, 2014) was used to conduct a real-life, contextually bound exploratory research that allowed for a deep dive into the lived experiences each participant and to contrast theme-based individual across the eleven cases of applied transgenerational social justice leadership (Flyvbjerg, 2006; Merriam, 1998; Salkind, 2010). Further, communal instruction and home pedagogy (Delgado Bernal, 2001; Collins, 1991) were considered to better grasp how Black student leaders enact in social justice while attending a PWI.

\section{Study Context}

This study was conducted at University of Whites (UW), a research intensive public PWI in a Southern state. The student body is comprised of 32,485 students and 1,299 self-identify as being a descendant of the African Diaspora or Black. As of 2018, approximately 481 (37\%) were men and the remaining $819(63 \%)$ were women. The legacy of UW is one of repeated racist that include White students wearing Blackface, conducting culturally deficit theme parties and vandalization of Black student property.

\section{Participants}

Purposeful sampling criterion (Patton, 1990) was applied to select eleven self-identifying Black student leaders, seven women and four men, who participated in the study. Criterion included: 1) self-identifying as Black; 2) held an elected or appointed position as a leader in a co-curricular student organization; and 3) considered themselves as an advocate of social justice. To disaggregate participant's leadership involvement data the Institutional Review Board (IRB) of UW received and approved our request to conduct the study, afterwards the UW Office of Diversity (OOD) emailed the study information Black collegians and though 26 responded, 11 were available to participate. Specifically, we used a snowball sampling technique with the initial participants who spread the word to friends about the research opportunity an although the abovementioned 26 were interested, 15 were unable to arrange availability to be interviewed due to predetermined class and work schedule.

Study participants were involved in at least three student organizations, each was five were second- and six were first-generation college going, averaging 20.5 years of age, the majority majored in STEM fields, nine lived on campus in residential housing, seven had accumulated at least 63 academic credits and each had earned a cumulative GPA of 3.2 or higher. Less than half of participants graduated from a predominately White high school prior to attending UW and only four participants were ineligible to receive financial aid. Participants' mothers' occupations ranged from vice principal, high school teacher, and comedian to corporate executive with degree attainment varying from high school diploma to doctoral degrees. Participants' fathers' occupations included a middle school coach, pastor, police officer, professional basketball player to a dentist with degree 
attainment ranging from a high school diploma to a masters' degree. Eight of the participants were from two-parent households, while grandparents raised two students. Nine of the participants were raised in urban environments, one in the suburbs and one in a rural town. Upon graduating, each participant planned to pursue graduate degree conferral. Consequently, three sought to enter the professoriate, two planned to start law school, three wanted to obtain a masters of business administration degree, two desired to enter medical school and the remaining participant planned to become a high school administrator.

\section{Data Collection and Analysis}

To explore how Black student leaders make sense of enacting social justice as a result of transgenerational racial socialization to navigate college, we conducted a comparative case study. Robust findings were yielded from eleven participants who provided in-depth information, as individual units of analysis, about their lived experiences (Yin, 2014). Three in-depth face-to-face interviews were conducted with each participant (i.e. 45 to 90 minutes) and a follow-up interview (i.e. 30 to 45 minute) for member checking purposes. According to Peräkylä \& Russuvuori (2011)

"In-depth interviews reach areas of reality that would otherwise remain inaccessible such as people's subjective experiences and attitudes. The interview is also a very convenient way of overcoming distances both in space and in time" (p. 529). Upon receiving signed consent forms interviews were recorded, notated and stored in the GarageBand program.

A constant comparative, line-by-line open coding method of data analysis was applied to facilitate the emergence of themes (Merriman, 1998). Utilizing a "broad brush-stroke representation called holistic coding" (Saldaña, 2016, p. 23) prepared us to better answer the posed research questions about transgenerational racial socialization. For instance, since participants acted as independent units of analysis (Yin, 2014) we were able to individually and comparatively conduct cross-case synthesis through separately coding interview then participating in a peer review, debriefing of the data sessions to provide an external check of sorts for the purpose of making certain we exhausted the data. Data were arranged, scrutinized, and lessened into themes by coding then condensing codes (Creswell, 2007) until categorical similarities, differences and behaviors were realized within the PWI context (Eisenhardt, 1989; Stake, 1995). Completing this process provided substantiated meaning about participant's understanding of navigating college.

\section{Results}

Findings contribute to research about how racial socialization informs the student identity development of Black collegians who are involved in leadership roles (Arminio et al., 2000; Dugan, 2006; Harper \& Quaye, 2007; Herndon \& Hirt, 2004; Hotchkins, 2017b; Hotchkins \& Dancy, 2017; Kelley, 2018; Peters, 1985; Stevenson, 1994) while purposefully enacting social justice on a PWI campus. Data analysis resulted in two emergent themes: (a) Collective Definition; and (b) Selfsacrifice. Participants explained that elders, parents and fictive kin racially socialized them to have high self-esteem, actively practice pro-Blackness and give back to their communities while being leaders in co-curricular organizations. The transgenerational racial socialization process instructed students about how to use leadership roles to develop and maintain Black student communities, in part through practicing racial resistance (Hotchkins, 2017b), which positively contributed to their resilience. Secondly, participants stated that although practicing social justice through using racial resistance was essential, they also found a sense of worth in expressing selfless, yet sacrificial modes of leadership to reinforce the preservation of a Black cultural collective while attending their PWIs.

Furthermore, participants frequently mentioned how elders, parents, and fictive kin racial 
socialized them, through sharing valuable transgenerational knowledge, about life lessons that bolstered their leadership practices. Transgenerational interactions spoke to both the rationale for Black progression and need to continue the legacy of social justice pursuits. Specifically, participants were taught how to identify, interrogate, and deconstruct sources of Black communal trepidation, in the past and present, to devise collective college navigational strategies. Interactive moments allowed for intellectual exchanges about what leading for social justice change can and should look like when practiced. Finally, participants appreciated transgenerational exchanges and eagerly anticipated being able to pay it forward across their adulthood.

\section{Collective Definition}

I remember growing up around my G-ma who would talk about how Black people of her time moved as a unit. Stories about how her father helped organize their communities to protect themselves are seared into my memory. He was a leader. (Quavo)

Quavo's sense making of Collective Definition stemmed from an understanding that not only does the Black community represent a collective whole, it is also attached to a notion of selfpreservation based on what he called a "symbiotic connectedness." Cardi spoke directly to this notion when she explained "although I am here [college] to earn a degree, everything I do is for my community because they expect me to be great even when I have doubts." The Collective Definition theme is defined acknowledging a commitment to the whole of Black people, actively laboring to achieve the emancipation of Black minds, bodies and Souls while purposefully conducting leadership acts that are geared to elevating Black communities. Quavo viewed his leadership success as informed by how elders, parents and fictive kin taught leading, their expected communal goals valuable lessons shared about the Civil Right era. Study participants described their ways of leading as explicitly informed by transgenerational stories and understood the application of histories told as prime to traversing the hostile UW campus climate. JT directly confirmed the value of transgenerational stories as helpful to navigating UW by recalling a conversation between himself and grandmother Janice "she said 'be in White spaces' to gather information from their groups to share with ours. Doing so, I learned about specific presidential scholarships told my organization constituents and one of them was selected when she applied."

Participants learned that purposeful strategy must be enacted in order to interrupt cyclical oppression so being a leader who intervenes is essential. "When my pops went to UW 21 years ago White students had Antebellum pro-Slavery parties and this was in the 90s. He shared how they responded to administration so I had the blueprint for the Blackface situation at UW" stated Meganthee. Meganthee's reflection is an example of transgenerational knowledge being passed in order to prepare for the inevitability of campus racism at PWIs. Participants valued transgenerational leadership knowledge because it spoke to the usage of successful strategies for emancipation within a PWI context and provided a cultural template for dismantling oppression. To bolster this point, Yung Miami explained how the advice of her uncle Coach K informed her tactics for addressing racism she experienced on campus:

Last Halloween, Kappa Alpha Order had a "cultural" party where participants dressed up as gangbangers with gold teeth, fake Afro wigs and wore blue bandanas. It was a mocking of stereotypical Black culture, which was offensive. I only knew about it because my White roommate Iggy was in attendance, took pics and DM'ed me. I told my uncle Coach $\mathrm{K}$ who gave me advice about how he would have handled it in his era and recommendations about what I needed to do. I meet with the UW 
Greek Affairs and as a result Black students developed an ad campaign called

"Culture Not a Costume" and film series about how to be a White Ally. That was my protest and it worked!

Subsequently, participants divulged about how being taught communal instruction as home pedagogy (Delgado Bernal, 2001; Collins, 1991) actively served as a communal repository of histories to be exchanged amongst Black student leaders for the betterment of the collective.

\section{Self-sacrifice(?)}

"Being a leader is challenging. Sometimes I invest more in Black people than I do myself. I lose sleep, stress out, and my grades have taken a hit, but I remain confident because my leadership makes a difference" (Cardi). Pierre elaborated: "I am the BSU president so the expectation is that I have all the answers so I will not let anyone down. I never want to be the reason Black students fail so sometimes personal sacrifices need to be made." The examples of Cardi and Pierre explain how self-sacrifice adversely impacts Black student leaders and why it is derived from an understanding of the value of diminishing oneself agenda to "lead for the people" (Kevin). Self-sacrifice(?) refers to participants' investment in enacting leadership to create community uplift while adversely impact themselves holistically; for instance, while attending UW Black student leaders frequently spent time in organization meetings, attending organization events and mentoring organization members instead of practicing self-care, studying or meeting with faculty to discuss academic outcomes. These quotes and theme speak to research by Guiffrida (2004) who found that involvement in Black student organizations can be academically detrimental to African American collegians who focused more on leadership and institutional change to benefit peers students over studying and earning good grades.

Stefflon lamented about the conundrum of being a successful Black leader "If I don't do it who will? If my leadership doesn't counteract the emptiness Black students feel at WTU, what good am I? I can be a better scholar for me, but I must be better for us." This belief participants' leadership practices were integral to Black communal successes created an interdependence that often resulted in students benefit and leader detriment. Kirshnik explained "the positive feeling I get from helping other Black students be successful is unmeasurable even though it feels like at times I am losing my sanity. Being the sacrificial lambs is part of it, but it is fulfilling!" However, transgenerational leadership knowledge(s) about how to enact measured self-sacrifice also proved helpful as many participants relied on elder and parental belief that "God will never place more on you than you can handle" (Quavo). This spiritual connectedness to elder perspectives illustrates the overlap of religious micro-systems and the permanence of chrono-systems (Bronfenbrenner, 2005) where parents, blood kin and fictive family members deep belief in an eternal higher power-Jesus as forever in power-served as a repeated example of the ultimate sacrifice, which was expected as a function of being Christian.

Kiari reflected about his father's experiences as an activist "he once talked about how dividing my time is going to be crucial to our [Black student] group success because if I flunk out it defeats the purpose, but sole focus is selfish." Kiari's response aligns with Lyons' (1973) research who found that "most of the leaders appeared to be in academic difficulty because of the tremendous amount of time required of them in the leadership role" (p. 464), which was spent mostly utilizing their organizations to help African American students negotiate the campus political landscape. Consequently, some participants were able to better balance organizational involvement and focusing on the "the main thing, which is graduating and getting a career started so I can give back to the community financially" (Meganthee). In many instances maintaining focus was a result 
of distributing organization work amongst members who wanted to occupy a leadership capacity, were willing to contribute or recognized the leader was overwhelmed and therefore wanted to make a similar sacrifice to mediate perceived stressors. Examples of these Black collegians bolstered the theme by describing how even though their organizations served as outlets for leadership engagement and campus involvement sources for the expression of social justice agendas and cultural identity (Fleming, 1984), it is not without a cost.

\section{Discussion and Implications}

By applying Bronfenbrenner's (1979, 1994, 2005) ecological paradigm coupled with Peters' (1985) racial socialization and Herndon \& Hirt (2004) fictive kin perspectives the authors demonstrated that transgenerational knowledge as transmitted to Black student leaders informs their pursuit of social justice while attending PWIs. In fact, participants purposefully led to uplift, emancipate and support Black peers attending UW despite the adverse personal impact—all due to a deep sense of Black communal connectedness. The presumed need to apply racial resistance (Hotchkins, 2017b) was attributed to racism experienced by participants at UW and undergirded by their micro-, meso-, exo-, macro-, and chrono-systematic (Bronfenbrenner, 1979, 1994, 2005) transgenerational, racial socialization learning processes. To this point, Black student leader ability to identify, strategize about how to endure and accurately locate hostile campus racial climate sources (Gusa, 2010; Hotchkins, 2017a; Hotchkins \& Dancy, 2017; Hurtado et al., 2015) proved beneficial to navigating college. Furthermore, participants understood that the verbiage of social justice coupled with protest actions raises the awareness of university faculty, administrators and staff who are oblivious to the notion that Black life is currently depreciated as a result of historic deficit framing, educational segregation and cultural exclusion.

\section{Social Justice as Informed by Micro-, Meso-, Exo-systems}

Participants understood social justice activism to be transgenerationally essential and to unfurl through co-curricular organizations as a function of communal assertion, never an individual act. Further, Black student leaders appreciated being racially socialized by elders, parents and fictive kin to have a Black self-awareness, bring resources to their communities, and live to dismantle stereotypes about Black people (Arminio et al., 2000; Dancy \& Hotchkins, 2015; Lavant \& Terrell, 1994; Hotchkins, 2017b). Subsequently, participants joined organizations actively pursued social justice through programming, tactics and admission of agendas with Black cultural and racial congruence. Moreover, transgenerationally racially socialized Black student leaders entered campus knowing "Black families are characterized by valuing extended kin relationships" (Herndon \& Hirt, 2004, p. 493) and understand that "power and politics are at the center of all teaching and learning, the application of household knowledge to situations outside of the home becomes a creative process that interrupts the transmission of 'official knowledge' and dominant ideologies" (Delgado Bernal, 2001, p. 624). In fact, participants' social justice leadership practices directly resulted from

nuclear in-home transgenerational interactions with parents (micro-); elder extended family proximal moments with great aunts, uncles, neighbors, church members and fictive kin (meso-); and local Prince Hall Masonic / $G \backslash$ or \#BlackLivesMatter organizations, which reinforced the need to preserve Black life (exo-) as a reminder descendants of the African Diaspora have been in a perpetual state of peril since arriving to the Americas in slave ships (Hartman, 2007; Womack, 2017). 


\section{Social Justice as Informed by Informed by Macro- and Chronosystems}

Participants' understanding of being Black and under siege due to individual and systemic racism were informed by macro-systems that historically practiced oppression toward themselves, families and community members. Bronfenbrenner (2005) defined the ecological macrosystem as occupying the superordinate level human development ecology: "it is the level involving culture, macroinstitutions (such as the federal government), and public policy. The macrosystem influences the nature of interaction within all other levels of the ecology of human development" (xiv). As a result, participants recognized subtle and blatant racist interactions with UW White peers, faculty and administrators (Brown, 2018; Hollingsworth, Patton, Allen \& Johnson, 2018; Kelly, 2018; Nadal et al., 2014; Robinson-Wood et al., 2015) as purposeful, while also being mindful of institutional racism occurring in K-12 school where zero-tolerance policies disproportionally compromised Black student learning throughout the city were UW was located. Participants constructed themselves as members of the African Diaspora and understood racism as a perpetual occurrence, which validates Bronfenbrenner's (1994) chronosystem as "change or consistency over time not only in the characteristics of the person but also of the environment in which that person lives," (p. 40) to include the belief that Black people live in the afterlife of surviving the transatlantic Slave trade (Hartman, 2007; Womack, 2017). Distinctly, the fact that participants learned about how racism manifests through communal instruction and home pedagogies (Collins, 1991; Delgado Bernal, 2001), as a function of racial socialization (Herndon \& Hirt, 2004; Peters, 1985), confirmed why participants viewed their racial identities as needing emancipation from varied forms of perpetual oppression within active chronosystems.

Study findings find that Black student leadership identity development is positively affected by the racial socialization process (Herndon \& Hirt, 2004; Peters, 1985; Stevenson, 1994) that is built upon interpersonal interactions (Bronfenbrenner, 1979, 1994, 2005) with Black elders, parents and fictive kin. Therefore, participants not only practiced social justice when leading to emancipate the Black cultural whole, but also applied racial resistance (Hotchkins, 2017b) to identify sources of racism then developed protective aversion strategies to grapple with the UW White institutional presence (Gusa, 2010). Similar to participants in the Hotchkins (2017b) study, these Black collegians not only "viewed racism as a perpetual system existing beyond the past and present by extending into the future as a source of trauma for unborn generations of Black people" (p. 278), but they also determined that if anything could end racism it would be found within cultural preparedness to resist. Therefore, perfecting the act of racial resistance was key to navigating UW and the need to do so justified the creation of ethnic enclaves or Black-centric places where appreciation for cultural commonalities and purposeful sharing of information could transpire. Finally, individual and collective knowledge about specific components of the UW hostile campus racial climate led to participants totally perform leadership for the precise purpose emancipating Black people through the application of social justice on campus and abroad.

\section{Implications for Practice}

Study findings certainly establish the value of elders, parents and fictive kin racial socialization processes (Herndon \& Hirt, 2004; Peters, 1985; Stevenson, 1994) to the Black identity of participants as shaped by proximal interpersonal interactions (Bronfenbrenner, 1979, 1994, 2005).

Subsequently, participants not only learned to perform acts of social justice, but also understood their generational connectedness to the Black community writ large, which further affirmed the lifelong commitment to use leadership roles in co-curricular organizations to dismantle systems of oppression that used racism to erase, exploit and silence Black people. Moreover, because 
participants framed racism part of a chronosystem that oppressed ancestors, elders, parents and fictive kin, based on hearing transgenerational narratives, they were prepared to make additional individual sacrifices to assure the stability of current and future Black communities. Additionally, participants leveraged leadership roles to conduct "give back" (Stefflon) opportunities for Black students through co-curricular organizations that had access to UW resources. Finally, although Black student leaders viewed themselves directly connected to the communities from whence they came domestically, there was also a heightened awareness of belonging to a global Black family that needed freeing from macroinstitutional processes such as White Colonization.

\section{References}

Allen, W. R. (1987). Gender and campus differences in Black student academic performance, racial attitudes, and college satisfaction. Southern Education Foundation.

Arminio, J. L., Carter, S., Jones, S. E., Kruger, K., Lucas, N., Washington, J., \& Scott, A. (2000). Leadership experiences of students of color. NASP A Journal, 37, 496-510. https://doi.org/10.2202/0027-6014.1112

Barlow, J. N. (2018). Restoring Optimal Black Mental Health and Reversing Intergenerational Trauma in an Era of Black Lives Matter. Biography, 41(4), 895-908. https://doi.org/10.1353/bio.2018.0084

Beachum, L. (2019, September 4). A noose was found hanging in a University of Illinois elevator. A student has been arrested. The W ashington Post. Retrieved from http://washingtonpost.com

Black, L. (2004). Ivory towers? The academy and racism. In I. Law, D. Phillips, \& L. Turney (Eds.), Institutional racism in higher education (pp. 1-6). Trentham Books.

Black, M. (2007). Fanon and DuBoisian double consciousness. Human Architecture: Journal of the Sociology of Self-knowledge, 5(3), 393-404.

Bowman, P., \& Howard, C. (1985). Race-related socialization, motivation, and academic achievement: A study of Black youths in three-generation families. Journal of the American Academy of Child Psychiatry, 24, 134-141. https:/ /doi.org/10.1016/S0002-7138(09)60438-6

Bronfenbrenner, U. (1979). The ecology of human development: Experiments by nature and design. Harvard University Press.

Bronfenbrenner, U. (1994). Ecological models of human development. In T. Husen \& T. N. Postlethwaite (Eds.), International encyclopedia of education (2nd. ed., Vol. 3, pp. 1643-1647). Pergamon/Elsevier.

Bronfenbrenner, U. (2005). Making human beings human. Sage.

Brown, K. D. (2018). Race as a durable and shifting idea: How Black millennial preservice teachers understand race, racism, and teaching. Peabody Journal of Education, 93(1), 106-120. https://doi.org/10.1080/0161956X.2017.1403183

Bryant, B. (2007). Thunder at Michigan and in the Heartland: Working for student empowerment and action. Morgan James Publishing.

Carter-Francique, A. R., Hart, A., \& Cheeks, G. (2015). Examining the value of social capital and social support for Black student-athletes' academic success. Journal of African American Studies, 19, 157-177. https://doi.org/10.1007/s12111-015-9295-z

Chatters, L. (2018). Exploring the moderating effects of racial/ ethnic socialization, academic motivation and African American racial identity on the relation between microaggressions and mattering of African American students at predominantly White institutions. (Publication No. 2100700579). [Doctoral dissertation, University of Nebraska - Lincoln]. ProQuest Dissertations Publishing. https://www.proquest.com/dissertations-theses/exploring-moderating-effects-racialethnic/docview/2100700579/se-2?accountid=201395 
Collins, P. H. (1991). Black feminist thought: Knowledge, consciousness, and the politics of empowerment. Routledge.

Cooke, D. Y. (2002). Racial discrimination and well-being among African American students. [Unpublished doctoral dissertation]. University of Michigan.

Creswell, J. W. (2007). Qualitative inquiry \& research design: Choosing among five approaches (2nd ed.). Sage.

Dancy, T. E. \& Hotchkins, B. K. (2015). Schools for the better making of men? Black undergraduate males, fraternity membership, and manhood. Culture, Society and Masculinities, 7, 7-21. https://doi.org/10.3149/CSM.0701.7

Delgado Bernal, D. (2001). Learning and living pedagogies of the home: The mestiza consciousness of Chicana students. Qualitative Studies in Education, 14, 623-639. https://doi.org/10.1080/09518390110059838

Dennis, J. M., Phinney, J. S., \& Chuateco, L. I. (2005). The role of motivation, parental support, and peer support in the academic success of ethnic minority first-generation college students. Journal of College Student Development, 46, 223-236. https://doi.org/10.1353/csd.2005.0023

DeSousa, J., \& Kuh, G. (1996). Does institutional racial composition make a difference in what black students gain from college? Journal of College Student Development, 37(3), 257-267. https://doi.org/10.1002/prac.18460370141

Dohrn, B., \& Ayers, W. (2016). Young, gifted, and Black: Black Lives Matter. In Conner, J., \& Rosen, S. (Eds.), Contemporary youth activism. Advancing social justice in the United States (pp. 7992). Praeger.

Dressier, W. (1987). Household structure in a Southern Black community. American Anthropologist, 87, 853-862. https://doi.org/10.1525/aa.1985.87.4.02a00070

Du Bois, W. E. B. (1903, 1994). The souls of Black folk. Gramercy Books.

DuBois, W. E. B. (1965). The souls of Black folk. In Three Negro classics (pp. 207-389). Avon Books. (Original work published 1903)

Dugan, J. P. (2006). Involvement and leadership: A descriptive analysis of socially responsible leadership. Journal of College Student Development, 47, 335-343. https://doi.org/10.1353/csd.2006.0028

Eisenhardt, K. (1989). Building theories from case study research. Academy of Management: The Academy of Management Review, 14, 532-550. https://doi.org/10.5465/amr.1989.4308385

Ervin, K. S. (2001). Multiculturalism, diversity, and African American college students: Receptive, yet skeptical? Journal of Black Studies, 31(6), 764-776. https://doi.org/10.1177/002193470103100604

Fanon, F. (1952). Black skin, White masks. Grove/Atlantic..

Fanon, F. (1967). Black skin, White masks (C. L. Markmann, Trans.) [Peau Noir, Masques Blancs]. Grove Weidenfeld. (Original work published 1952)

Fleming, J. (1984). Blacks in college: A comparative study of student success in Black and White institutions. Jossey-Bass.

Flowers, F. A. (2002). The impact of college racial composition on African American students' academic and social gains: Additional evidence. Journal of College Student Development, 43, 403410.

Flyvbjerg, B. (2006). Five misunderstandings about case-study research. Qualitative Inquiry, 12, 219245. https://doi.org/10.1177/1077800405284363

Garza, A. (2014, October 7). A herstory of the \#blacklivesmatter movement by Alicia Garza. The Feminist Wire. http:/ /www.thefeministwire.com/2014/10/blacklivesmatter-2/ 
Gin, K. J., Martínez-Alemán, A. M., Rowan-Kenyon, H. T., \& Hottell, D. (2017). Racialized aggressions and social media on campus. Journal of College Student Development, 58, 159- 174. https://doi.org/10.1353/csd.2017.0013

Guiffrida, D. A. (2004). Friends from home: Asset and liability to African American students attending a predominantly White institution. NASPA Journal, 41(4), 693-708. https://doi.org/10.2202/0027-6014.1394

Gusa, D. L. (2010). White institutional presence: The impact of Whiteness on campus climate. Harvard Educational Review, 80, 464-489. https://doi.org/10.17763/haer.80.4.p5j483825u110002

Harper, F. D. (1975). Black students, White campuses. APGA Press.

Harper, S. R., \& Hurtado, S. (2007). Nine themes in campus racial climates and implications for institutional transformation. In S. R. Harper \& L. D. Patton (Eds.), Responding to the realities of race on campus (pp. 7-24). Jossey-Bass.

Harper, S. R., \& Quaye, S. J. (2007). Student organizations as venues for Black identity expression and development among African American male student leaders. Journal of College Student Development, 48, 127-144. https://doi.org/10.1353/csd.2007.0012

Harris, J. C., Haywood, J. M., Ivery, S. M., \& Shuck, J. R. (2015). 'Yes, I Am Smart!”: Battling microaggressions as women of color doctoral students. In J. L. Martin (Ed.), Racial battle fatigue: Insights from the front lines of social justice advocacy (pp. 151-162). Praeger.

Hartman, S. (2007). Lose your mother: A journey along the Atlantic Slave Route. Farrar, Straus and Giroux.

Herndon, M. K., \& Hirt, J. B. (2004). Black students and their families: What leads to success in college. Journal of Black Studies, 34, 489-513. https://doi.org/10.1177/0021934703258762

Hernandez, E. (2019, September 11). CSU won't punish students who wore blackface in photo shared on social media, citing First Amendment. The Denver Post. http://www.thedenverpost.com

Hollingsworth, L. D., Patton, D. U., Allen, P. C., \& Johnson, K. E. (2018). Racial microaggressions in social work education: Black students' encounters in a predominantly White institution. Journal of Ethnic \& Cultural Diversity in Social Work, 27(1), 95-105. https://doi.org/10.1080/15313204.2017.1417942

Hotchkins, B. K. (2017a). Black women students at predominantly White universities: Narratives of identity politics, well-being and leadership mobility. NASP A Journal about Women in Higher Education, 10, 32-52. https://doi.org/10.1080/19407882.2017.1326943

Hotchkins, B. K. (2017b). Black student leaders practicing resistance in the midst of chaos: Applying transgenerational activist knowledge to navigate a predominantly white institution. The Journal of Negro Education, 86(3), 269-282. https://doi.org/10.7709/jnegroeducation.86.3.0269

Hotchkins, B. K., \& Dancy, T. E. (2017). A house is not a home: Black students' responses to racism in university residential halls. Journal of College and University Student Housing, 43, 40-51. https://doi.org/10.7709/jnegroeducation.86.3.0269

Hurtado, S., Alvarado, A. R., \& Guillermo-Wann, C. (2015). Thinking about race: The salience of racial identity at two-and four-year colleges and the climate for diversity. The Journal of Higher Education, 86, 127-155. https://doi.org/10.1353/jhe.2015.0000

Hurtado, S., Milem, J., Clayton-Pedersen, A. \& Allen, W. (1998). Enhancing campus climates for racial/ethnic diversity: Educational policy and practice. The Review of Higher Education, 21(3), 279-302.

Johnson, A., \& Lane, T. B. (2016). Understanding educational interventions that enhance social capital among Black urban parents and college students: A comparative case study. Urban Education Research and Policy Annuals, 4, 105-122. 
Joshi, K. D., Trauth, E., Kvasny, L., Morgan, A. J., \& Payton, F. C. (2017). Making Black Lives Matter in the information technology profession: Issues, perspectives, and a call for action. ACM SIGMIS Database: The DATABASE for Advances in Information Systems, 48, 21-34. https://doi.org/10.1145/3084179.3084183

Joseph, P. E. (2003). Dashikis and democracy: Black studies, student activism, and the Black Power Movement. The Journal of African American History, 88, 182-203. https://doi.org/10.2307/3559065

Kelley, R. D. (2018). Black study, black struggle. Ufahamu: A Journal of African Studies, 40(2), 153-168.

Kiah, C. W. (1992). The relationship of Black students' achievement motivation to family cohesion and specific aspirations. In Lang, M. \& Ford, C. (Eds.), Strategies for retaining minority students in bigher education (pp. 45-53). Charles C. Thomas.

Kimbrough, W. (1995). Self-assessment, participation, and value of leadership skills, activities, and experiences for Black students relative to their membership in historically Black fraternities and sororities. Journal of Negro Education, 64, 63-74. https://doi.org/10.2307/2967285

Kimbrough, W. M., \& Hutcheson, P.A. (1998). The impact of membership in Black Greek-letter organizations on Black students' involvement in collegiate activities and their development of leadership skills. The Journal of Negro Education, 67, 96-105. https://doi.org/10.2307/2668220

Kirker, S. (2019a, September 22). OU's Black Emergency Response Team alerts community to blackface incident. OU Daily. Retrieved from http://www.oudaily.com

Krause, K. H., Miedema, S. S., Woofter, R., \& Yount, K. M. (2017). Feminist research with student activists: Enhancing campus sexual assault research. Family Relations, 66, 211-223. https://doi.org/10.1111/ fare.12239

Lavant, B., \& Terrell, M. (1994). Assessing ethnic minority student leadership and involvement in student governance. New Directions for Student Services, 66, 59-71. https://doi.org/10.1002/ss.37119946607

Lyons, J. (1973). The adjustment of Black students to predominantly White campuses. The Journal of Negro Education, 42(4), 462-466. https://doi.org/10.2307/2966559

McAdoo, H. P. (Ed.). (1993). Family ethnicity: Strength in diversity. Sage.

Merriam, S. B. (1998). Qualitative resign and case study applications in educations. Jossey-Bass.

Morris, A. (1981). Black southern student sit-in movement: An analysis of internal organization. American Sociological Review, 46, 744-767. https://doi.org/10.2307/2095077

Nadal, K. L., Wong, Y., Griffin, K. E., Davidoff, K., \& Sriken, J. (2014). The adverse impact of racial microaggressions on college students' self-esteem. Journal of College Student Development, 55, 461-474. https://doi.org/10.1353/csd.2014.0051

Patton, M. Q. (1990). Qualitative evaluation and research methods (2nd ed.). Sage.

Patton, L., Flowers, L. \& Bridges, B. (2011). Effects of Greek affiliation on African American student's engagement: Differences by college racial composition. College Student Affairs Journal, 29(2), 113-123.

Peniel, J. (2003). Dashikis and democracy: Black studies, student activism, and the Black power movement. Journal of African American History, 88(2), 182-203. https://doi.org/10.2307/3559065

Peräkylä, A., \& Russuvuori, J. (2011). Analyzing talk and text. In N. K. Denzin \& Y. S. Lincoln (Eds.), The Sage handbook of qualitative research (4th ed.; pp. 529-544). Sage.

Person, D. R. \& Christensen, M. C. (1996). Understanding Black student culture and Black student retention. NASPA Journal, 34(1), 47-56. 
Peters, M. F. (1985). Racial socialization of young Black children. In H. P. McAdoo \& J. L. McAdoo, (Eds.), Black children: Social, educational, and parental environments (pp. 159-173). Sage.

Peters, M. A., \& Besley, T. (2017). White supremacism: The tragedy of Charlottesville. Educational Philosophy and Theory, 49(14), 1309-1312. https://doi.org/10.1080/00131857.2017.1370896

Rankin, S. R., \& Reason, R. D. (2005). Differing perceptions: How students of color and white students perceive campus climate for underrepresented group. Journal of College Student Developments, 46(1), 43-61. https://doi.org/10.1353/csd.2005.0008

Renn, K. A. (2007). LGBT student leaders and queer activists: Identities of lesbian, gay, bisexual, transgender, and queer identified college student leaders and activists. Journal of College Student Development, 48, 311-330. https://doi.org/10.1353/csd.2007.0029

Robinson-Wood, T., Balogun-Mwangi, O., Fernandes, C., Popat-Jain, A., Boadi, N., Matsumoto, A., \& Zhang, X. (2015). Worse than blatant racism: A phenomenological investigation of microaggressions among Black women. Journal of Ethnographic \& Qualitative Research, 9, 221236. https://dx.doi.org/10.1037/qup0000113

Rosenthal, J. (1975). Southern Black student activism: Assimilation vs. nationalism. The Journal of Negro Education, 44, 113-129. https://doi.org/10.2307/2966647

Saldaña, J. (2016). The coding manual for qualitative researchers. Sage.

Salkind, N. J. (2010). Encyclopedia of research design. Sage.

Sandoval-Almazan, R., \& Gil-Garcia, J. R. (2014). Towards cyberactivism 2.0? Understanding the use of social media and other information technologies for political activism and social movements. Government Information Quarterly, 31, 365-378. https://doi.org/10.1016/j.giq.2013.10.016

Schuschke, J. \& Tynes, B. M. (2016). Online community empowerment, emotional connection, and armed love in the Black Lives Matter Movement. In S. Tettegah (Ed.), Emotions, technology, and social media (pp. 25-48). Academic Press.

Shalby, C. (2019, July 18). Stanford investigating after noose hanging from tree is found on campus. The Los Angeles Times. Retrieved from http://latimes.com

Smith, W. A., Allen, W. R., \& Danley, L. L. (2007). "Assume the position . . Y You fit the description": Psychosocial experiences and racial battle fatigue among African American male college students. American Behavioral Scientist, 51, 551-578. https://doi.org/10.1177/0002764207307742

Sawyer III, D. C., \& Palmer, R. T. (2014). A different kind of Black, but the same issues: Black males and counterstories at a predominantly White institution. Journal of Progressive Policy and Practice, 2, 255-272.

Stake, R. (1995). The art of case study research. Sage.

Stevenson, H. (1994). Racial socialization in African American families: The art of balancing intolerance and survival. The Family Journal: Counseling and Therapy for Couples and Families, 2, 190-198. https://doi.org/10.1177/1066480794023002

Sue, D. W. (2010). Microaggressions in everyday life: Race, gender, and sexual orientation. Wiley.

Sutton, E., \& Kimbrough, W. (2001). Trends in Black student involvement. NASPA Journal, 39, 3040. https://doi.org/10.2202/0027-6014.1160

Thompson, J. (2000). Shattering the barriers: Achieving African Americans at a predominately white research university in the south and the reasons for their success. (Unpublished doctoral dissertation). Louisiana State University and Agricultural Mechanical College.

Wallace, D. L., \& Bell, A. (1999). Being black at a predominately white university. College English, 61(3), 307-327. https://doi.org/10.2307/379071 
White, K. (2016). Black lives on campuses matter: reflecting on the rise of the new Black student movement. Soundings, 63, 86-97. https://doi.org/10.3898/136266216819377002

Womack, A. (2017). Visuality, surveillance, and the afterlife of slavery. American Literary History, 29, 191-204. https://doi.org/10.1093/alh/ajw061

Yin, R.K. (2014). Case study research: Design and methods (5th ed.). Sage.

\section{About the Authors}

\section{Bryan K. Hotchkins}

Texas Tech University

Email address: bryan.hotchkins@,ttu.edu

ORCID: https://orcid.org/0000-0002-6057-0246

Bryan K. Hotchkins is an assistant professor at Texas Tech University. A critical race pedagogue, Dr. Hotchkins studies how people of African descent experience racial trauma within organizations based on climate, context and culture. More specifically, his research problematizes issues pertaining to the intersection of leadership, activism and access across $\mathrm{K}$ 20 educational contexts. Dr. Hotchkins' research is guided by questions related to how institutional environments and racial constructions influence student, faculty and administrator involvement on campus.

\section{Jon McNaughtan}

Texas Tech University

Email address: jon.mcnaughtan@,ttu.edu

ORCID: https://orcid.org/0000-0003-4357-9457

Jon McNaughtan is an assistant professor at Texas Tech University where his research focuses on the role and experience of college leaders, with an emphasis on presidents. In this vein he has studied how presidents are selected, their communication strategies during time of crisis, and how they ganged with campus stakeholders. Through this line of work he hopes to assist in the development of future college leaders.

\section{About the Guest Editors}

\section{Irina S. Okhremtchouk}

San Francisco State University

Email address: irinao@sfsu.edu

Irina S. Okhremtchouk is an associate professor of educational administration in the Department of Equity, Leadership Studies, and Instructional Technologies at San Francisco State University's

Graduate College of Education. She also coordinates SFSU's educational administration certification and educational administration MA programs. In her capacity as educational administration program coordinator, Okhremtchouk is charged with preparing well-rounded and well-informed social justice leaders and school administrators who are ready to build and maintain inclusive school communities, as well as work persistently to eliminate racism, inequalities, and injustices. Okhremtchouk's expertise is in the area of school organization, policy, and school finance. Specifically, her scholarly work stems from a deep interest in how to translate research into better-informed public policy yielding a long-lasting impact on educational leadership, policy, and administration. Irina received her Ph.D. in School Organization and Educational Policy from the U.C. Davis School of Education. 


\section{Caroline Sotello Viernes Turner}

California State University, Sacramento

Email address: csturner@,csus.edu

An internationally recognized and award-winning scholar, Caroline Sotello Viernes Turner is professor emerita of educational leadership at California State University, Sacramento, and Lincoln Professor Emerita of Higher Education and Ethics at Arizona State University. She served as president of the Association for the Study of Higher Education (ASHE) and as interim dean for the College of Education at California State University, Sacramento. She is the author of Women of Color in Academe: Living with Multiple Marginality and coauthor with Samuel L. Myers Jr. of Faculty of Color in Academe: Bittersweet Success. Her numerous recognitions include the University of California, Davis (UCD) School of Education Distinguished Alumna Award and the American Educational Research Association (AERA) Scholars of Color in Education Career Contribution Award. She received her Ph.D. in Administration and Policy Analysis from the Stanford University School of Education.

\section{Patrick Newell}

California State University, Chico

Email address: pnewell@,csuchico.edu

Patrick Newell serves as Dean of Meriam Library at California State University, Chico. His research efforts focus on policy implications for access to educational and informational resources and how education policy translates into institutional change. He received his Ph.D. in School Organization and Educational Policy from the U.C. Davis School of Education and his MLIS from the UCLA Graduate School of Education and Information Studies.

\section{SPECIAL ISSUE \\ Striving for Social Justice and Equity in Higher Education \\ education policy analysis archives}

Volume 29 Number 42

March 29, 2021

ISSN 1068-2341

(c) (1) (2)

Readers are free to copy, display, distribute, and adapt this article, as long as the work is attributed to the author(s) and Education Policy Analysis

Archives, the changes are identified, and the same license applies to the derivative work. More details of this Creative Commons license are available at https://creativecommons.org/licenses/by-sa/4.0/. EPAA is published by the Mary Lou Fulton Institute and Graduate School of Education at Arizona State University Articles are indexed in CIRC (Clasificación Integrada de Revistas Científicas, Spain), DIALNET (Spain), Directory of Open Access Journals, EBSCO Education Research Complete, ERIC, Education Full Text (H.W. Wilson), QUALIS A1 (Brazil), SCImago Journal Rank, SCOPUS, SOCOLAR (China).

Please send errata notes to Audrey Amrein-Beardsley at audrey.beardsley@asu.edu

Join EPAA's Facebook community at https://www.facebook.com/EPAAAAPE and Twitter feed@epaa_aape. 


\section{education policy analysis archives editorial board}

Lead Editor: Audrey Amrein-Beardsley (Arizona State University)

Editor Consultor: Gustavo E. Fischman (Arizona State University)

Associate Editors: Melanie Bertrand, David Carlson, Lauren Harris, Danah Henriksen, Eugene Judson, Mirka

Koro-Ljungberg, Daniel Liou, Scott Marley, Keon McGuire, Molly Ott, Iveta Silova (Arizona State University)

Madelaine Adelman Arizona State

University

Cristina Alfaro

San Diego State University

Gary Anderson

New York University

Michael W. Apple

University of Wisconsin, Madison

Jeff Bale University of Toronto,

Canada

Aaron Benavot SUNY Albany

David C. Berliner

Arizona State University

Henry Braun Boston College

Casey Cobb

University of Connecticut

Arnold Danzig

San Jose State University

Linda Darling-Hammond

Stanford University

Elizabeth H. DeBray

University of Georgia

David E. DeMatthews

University of Texas at Austin

Chad d'Entremont Rennie Center

for Education Research \& Policy

John Diamond

University of Wisconsin, Madison

Matthew Di Carlo

Albert Shanker Institute

Sherman Dorn

Arizona State University

Michael J. Dumas

University of California, Berkeley

Kathy Escamilla

University of Colorado, Boulder

Yariv Feniger Ben-Gurion

University of the Negev

Melissa Lynn Freeman

Adams State College

Rachael Gabriel

University of Connecticut
Amy Garrett Dikkers University

of North Carolina, Wilmington

Gene V Glass

Arizona State University

Ronald Glass University of

California, Santa Cruz

Jacob P. K. Gross

University of Louisville

Eric M. Haas WestEd

Julian Vasquez Heilig California

State University, Sacramento

Kimberly Kappler Hewitt

University of North Carolina

Greensboro

Aimee Howley Ohio University

Steve Klees University of Maryland

Jaekyung Lee SUNY Buffalo

Jessica Nina Lester

Indiana University

Amanda E. Lewis University of

Illinois, Chicago

Chad R. Lochmiller Indiana

University

Christopher Lubienski Indiana

University

Sarah Lubienski Indiana University

William J. Mathis

University of Colorado, Boulder

Michele S. Moses

University of Colorado, Boulder

Julianne Moss

Deakin University, Australia

Sharon Nichols

University of Texas, San Antonio

Eric Parsons

University of Missouri-Columbia

Amanda U. Potterton

University of Kentucky

Susan L. Robertson

Bristol University
Gloria M. Rodriguez

University of California, Davis

R. Anthony Rolle

University of Houston

A. G. Rud

Washington State University

Patricia Sánchez University of

University of Texas, San Antonio

Janelle Scott University of

California, Berkeley

Jack Schneider University of

Massachusetts Lowell

Noah Sobe Loyola University

Nelly P. Stromquist

University of Maryland

Benjamin Superfine

University of Illinois, Chicago

Adai Tefera

Virginia Commonwealth University

\section{A. Chris Torres}

Michigan State University

Tina Trujillo

University of California, Berkeley

Federico R. Waitoller

University of Illinois, Chicago

Larisa Warhol

University of Connecticut

John Weathers University of

Colorado, Colorado Springs

Kevin Welner

University of Colorado, Boulder

Terrence G. Wiley

Center for Applied Linguistics

John Willinsky

Stanford University

Jennifer R. Wolgemuth

University of South Florida

Kyo Yamashiro

Claremont Graduate University

Miri Yemini

Tel Aviv University, Israel 


\section{conselho editorial}

Editor Consultor: Gustavo E. Fischman (Arizona State University)

Editoras Coordenadores: Marcia Pletsch, Sandra Regina Sales (Universidade Federal Rural do Rio de Janeiro) Editores Associadas: Andréa Barbosa Gouveia (Universidade Federal do Paraná), Kaizo Iwakami Beltrao, (EBAPE/FGVl), Sheizi Calheira de Freitas (Federal University of Bahia), Maria Margarida Machado, (Federal University of Goiás / Universidade Federal de Goiás), Gilberto José Miranda, (Universidade Federal de Uberlândia, Brazil), Maria Lúcia Rodrigues Muller (Universidade Federal de Mato Grosso e Science)

\author{
Almerindo Afonso \\ Universidade do Minho \\ Portugal \\ Rosanna Maria Barros Sá \\ Universidade do Algarve \\ Portugal

\section{Maria Helena Bonilla \\ Universidade Federal da Bahia \\ Brasil}

\author{
Rosa Maria Bueno Fischer \\ Universidade Federal do Rio Grande \\ do Sul, Brasil
}

\section{Alice Casimiro Lopes \\ Universidade do Estado do Rio de \\ Janeiro, Brasil}

\section{Suzana Feldens Schwertner \\ Centro Universitário Univates \\ Brasil \\ Geovana Mendonça Lunardi \\ Mendes Universidade do Estado de \\ Santa Catarina}

Flávia Miller Naethe Motta

Universidade Federal Rural do Rio de

Janeiro, Brasil

\section{Alexandre Fernandez Vaz \\ Universidade Federal de Santa \\ Catarina, Brasil}

\section{Regina Célia Linhares Hostins \\ Universidade do Vale do Itajaí, \\ Brasil}

\section{Alfredo Macedo Gomes \\ Universidade Federal de Pernambuco \\ Brasil}

\section{Jefferson Mainardes}

Universidade Estadual de Ponta

Grossa, Brasil

Jader Janer Moreira Lopes

Universidade Federal Fluminense e

Universidade Federal de Juiz de Fora,

Brasil

Debora Nunes

Universidade Federal do Rio Grande do Norte, Brasil

\author{
Alda Junqueira Marin \\ Pontifícia Universidade Católica de \\ São Paulo, Brasil
}

Dalila Andrade Oliveira

Universidade Federal de Minas

Gerais, Brasil
José Augusto Pacheco

Universidade do Minho, Portugal

Jane Paiva

Universidade do Estado do Rio de Janeiro, Brasil

\section{Paulo Alberto Santos Vieira \\ Universidade do Estado de Mato \\ Grosso, Brasil}

Fabiany de Cássia Tavares Silva

Universidade Federal do Mato

Grosso do Sul, Brasil

\section{António Teodoro}

Universidade Lusófona

Portugal

\section{Lílian do Valle}

Universidade do Estado do Rio de Janeiro, Brasil

\author{
Alfredo Veiga-Neto \\ Universidade Federal do Rio Grande \\ do Sul, Brasil
}




\section{archivos analíticos de políticas educativas consejo editorial}

Editor Consultor: Gustavo E. Fischman (Arizona State University)

Coordinador (Español / Latinoamérica): Ignacio Barrenechea, Axel Rivas (Universidad de San Andrés

Editor Coordinador (Español / Norteamérica): Armando Alcántara Santuario (Universidad Nacional Autónoma de México)

Editor Coordinador (Español / España): Antonio Luzon (Universidad de Granada)

Editores Asociados: Felicitas Acosta (Universidad Nacional de General Sarmiento), Jason Beech (Universidad de San Andrés), Angelica Buendia, (Metropolitan Autonomous University), Alejandra Falabella (Universidad Alberto Hurtado, Chile), Veronica Gottau (Universidad Torcuato Di Tella), Carolina Guzmán-Valenzuela (Universidade de Chile), Cesar Lorenzo Rodriguez Uribe (Universidad Marista de Guadalajara

María Teresa Martín Palomo (University of Almería), María Fernández Mellizo-Soto (Universidad Complutense de Madrid), Tiburcio Moreno (Autonomous Metropolitan University-Cuajimalpa Unit), José Luis Ramírez, (Universidad de Sonora), Maria Veronica Santelices (Pontificia Universidad Católica de Chile)

Claudio Almonacid

Universidad Metropolitana de Ciencias de la Educación, Chile

Miguel Ángel Arias Ortega

Universidad Autónoma de la

Ciudad de México

Xavier Besalú Costa

Universitat de Girona, España

Xavier Bonal Sarro Universidad

Autónoma de Barcelona, España

Antonio Bolívar Boitia

Universidad de Granada, España

José Joaquín Brunner Universidad

Diego Portales, Chile

Damián Canales Sánchez

Instituto Nacional para la

Evaluación de la Educación,

México

Gabriela de la Cruz Flores

Universidad Nacional Autónoma de

México

Marco Antonio Delgado Fuentes

Universidad Iberoamericana,

México

Inés Dussel, DIE-CINVESTAV, México

Pedro Flores Crespo Universidad Iberoamericana, México
Ana María García de Fanelli

Centro de Estudios de Estado y

Sociedad (CEDES) CONICET,

Argentina

Juan Carlos González Faraco

Universidad de Huelva, España

María Clemente Linuesa

Universidad de Salamanca, España

Jaume Martínez Bonafé

Universitat de València, España

Alejandro Márquez Jiménez

Instituto de Investigaciones sobre la Universidad y la Educación,

UNAM, México

María Guadalupe Olivier Tellez, Universidad Pedagógica Nacional, México

Miguel Pereyra Universidad de Granada, España

Mónica Pini Universidad Nacional de San Martín, Argentina

Omar Orlando Pulido Chaves

Instituto para la Investigación

Educativa y el Desarrollo

Pedagógico (IDEP)

José Ignacio Rivas Flores

Universidad de Málaga, España
Miriam Rodríguez Vargas

Universidad Autónoma de

Tamaulipas, México

José Gregorio Rodríguez

Universidad Nacional de Colombia, Colombia

Mario Rueda Beltrán Instituto de Investigaciones sobre la Universidad y la Educación, UNAM, México

José Luis San Fabián Maroto

Universidad de Oviedo, España

Jurjo Torres Santomé, Universidad de la Coruña, España

Yengny Marisol Silva Laya

Universidad Iberoamericana,

México

Ernesto Treviño Ronzón

Universidad Veracruzana, México

Ernesto Treviño Villarreal

Universidad Diego Portales

Santiago, Chile

Antoni Verger Planells

Universidad Autónoma de

Barcelona, España

Catalina Wainerman

Universidad de San Andrés, Argentina

Juan Carlos Yáñez Velazco

Universidad de Colima, México 